\title{
Project management: How to ASSESS A PROJECT'S SUCCESS
}

\author{
Zita Prostejovska*1, Jaroslava Tomankova ${ }^{2}$ \\ ${ }^{1}$ VSEM, Narozni 2600/9A, 15800 Prague, Czech Republic \\ ${ }^{2}$ VSEM, Narozni 2600/9A, 15800 Prague, Czech Republic
}

\begin{abstract}
Today the Iron Triangle (cost, time and quality) is insufficient as a sole factor of a project's success. Other criteria need to be considered, which will allow stakeholders to accept results of the project. Underestimating these factors can lead to a negative attitude by stakeholders and thus to obstructions while implementing the project, which in turn can cause the Iron Triangle criteria not to be fulfilled - cost overruns, exceeded time schedule etc.

This article presents a structured review of the theoretical issues of project management related literature and based on practical experience in managing construction projects, the authors propose criteria for evaluating the success of these projects. The proposed criteria and their influence on a project are demonstrated in a case study on a selection of construction projects. This article also gives a possible practical approach to evaluate a project's success.
\end{abstract}

\section{Keywords}

Project management, project success criteria, triple constrain, project success evaluation

\section{JEL Classification}

H43, L74, O21

DOI: https://doi.org/10.14311/bit.2017.01.01

Editorial information: journal Business \& IT, ISSN 2570-7434, CreativeCommons license (c) (i) published by CTU in Prague, 2017, http://bit.fsv.cvut.cz/ 


\section{Introduction}

Project success and its evaluation are widely discussed topics in project management. The basic criterion is compliance with Iron Triangle - cost, time and quality. Many authors point out that these three criteria are not sufficient and it is necessary to cover interests of different groups of stakeholders. Stakeholders' expectations bring unique criteria into every type of project; they are mostly subjective and their objective evaluation is difficult.

According to research by [2], 50\% of internal projects in the Czech Republic are unsuccessful and a similar source [3] states that a project's failure is usually due to different expectations among the stakeholders about project outcomes. That could suggest not knowing or not taking into account stakeholders' attitude during project preparation.

This article aims to design criteria for evaluating the success of construction projects and to verify their significance in a case study on a sample of construction projects.

\section{Literature review}

The definition of project management has changed over the years. Atkinson [1] pointed out that the first definitions included success criteria as time, quality and money. These criteria are known as Iron Triangle or Triple Constraint (Fig. 1) [8]. The Project Management Body of Knowledge [8] defined project management more generally, as "the application of knowledge, skills, tools and techniques to project activities to meet the project requirements." On the other hand, current definitions of project often include the main three criteria mentioned (ISO 21 500:2012) [4].

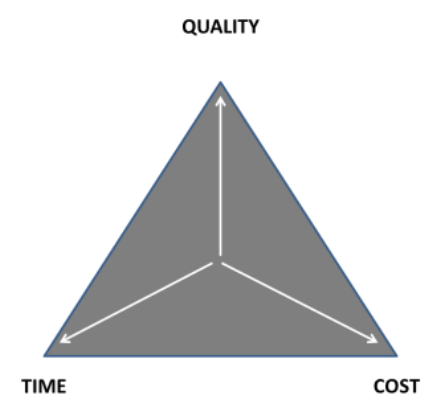

Fig. 1. Iron Triangle (Source: [8])

Despite the fact that the basic criteria mentioned - cost, time and quality - are measurable, many projects failed. Munns and Bjeirmi [6] stated that project success also depends on other criteria than the Iron Triangle. Atkinson [1] proposed The Square route which divides success criteria into four groups:

- Iron Triangle

- The information system

- Benefits for organization

- Stakeholder's benefits

During the past years much more authors have presented different research or surveys focused on project success criteria. Westerveld [10] mentioned that aside from project success criteria there are also project success factors. Many authors deal with identifying the factors that are necessary for a 
successful completion of a project. Cook-Davies [11] identified 12 key success factors divided into three groups:

- Factors of project management success

- Factors of project success

- Factors of consistently successful projects

Westerveld [10] introduced the Project excellence model which is based on EFQM-model and distinguished Project success criteria (results factors) and Critical success factors (organizational factors).

For different types of projects (e.g. internal $x$ external) there are specific ways of determining and evaluating both success factors and success criteria. Wai et al. [9] proposed a methodology of assessing project success of social infrastructure projects and identified 41 success factors which are divided into 8 basic components that express the phases of a project and the internal factors (e.g. organizational, informational and change management). The approach presented by Wai et al. [9] does not take into account the attitudes of stakeholders, even though these projects are sensitive to these attitudes.

On the contrary, Olander and Landin [7] take the changing attitudes of stakeholders during the life cycle of construction projects into consideration and stress the importance of good communication in the early stages of a project. As the author states, stakeholders can have a positive or a negative influence on the course of the project and it is necessary to recognize different groups and their various attitudes towards it.

\section{Methodology}

The study is based on a detailed research of literature on evaluating the success of projects, criteria and success factors. The proposed evaluation criteria are based on the analysis of a project's context and, in particular, on the specifics of construction projects. The authors utilized their long-term experience with construction projects to define and structure the problem. The relevance of the proposed evaluation criteria was verified in a case study on a sample of 25 construction projects. Depending on the nature of individual criteria, the methods of their measurement were determined. For the quantitative criteria, evaluation was based on the percentage deviation from the planned values, for the qualitative criteria, a three-value expert evaluation was used. The results of the study are discussed in the Conclusion.

\section{Proposal of project success evaluation based on criteria}

Based on literature review and experience with construction projects we propose criteria for evaluating the success of such projects.

The category of construction projects includes projects of various sizes and purposes and the evaluation of their success can differ in certain sub-parameters. All of them however maintain the same Iron Triangle criteria (time, cost, quality). All projects are also to a degree influenced by stakeholders; in the project preparation phase they are mainly the relevant authorities, the building office, neighboring property owners and possibly the public in the form of various interest groups. Projects are further limited by their context (legislation, environment). One of the success criteria is also good project management, i.e. organization during the project's execution.

Proposed criteria are divided into 4 groups as shown in Fig. 2. Evaluation of the Iron Triangle group of criteria can be done using quantitative indicators (e.g. deviation from requirement in \%), other groups can be evaluated qualitatively. 


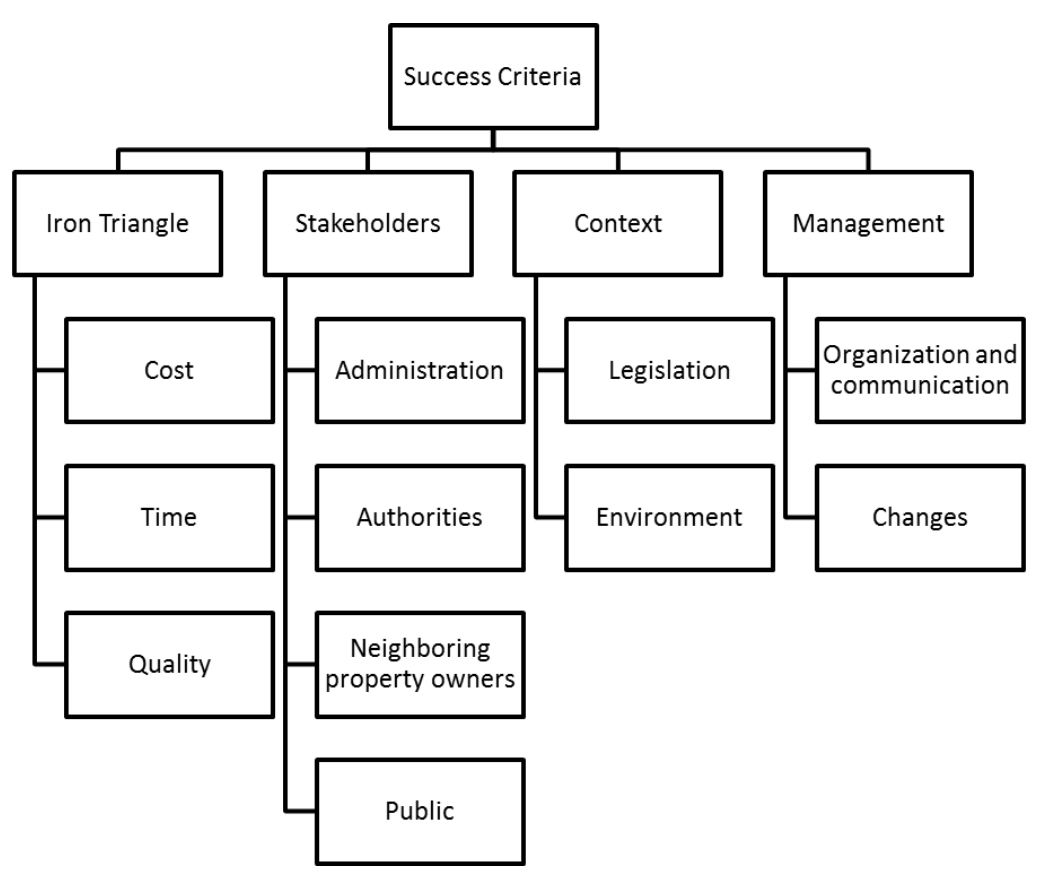

Fig. 2. Success Criteria (source: authors)

The proposed criteria and their influence on a project are demonstrated on a selection of lower- to medium-scale construction projects.

\section{Case study}

The project success evaluation is conducted on a sample of 25 construction projects. This sample includes 24 family houses and one office building project (Project 25).

The method of evaluating individual criteria for the selected projects listed in Table 1 is as follows:

- Cost and Time criteria are expressed as a percent deviation from plan

- all other criteria are evaluated qualitatively on a scale:

- a - in accordance with requirements

- $b$-small deficiencies or problems to be addressed with little impact on the project

- $\mathrm{c}$ - large deficiencies with great impact on the project

Table 1 clearly shows that the projects suffered most often from cost and time overruns, i.e. Iron Triangle criteria. The examined sample of projects also reveals frequent changes, $1 / 4$ of which are very significant. The Context criteria did not greatly influence these small-scale projects, but it is necessary to note that the significance of these criteria is proportional to the size of the project and its impact on the environment.

The same conclusion can be made about the Public criteria. The Stakeholders group of criteria influenced more than $50 \%$ of projects in the evaluated sample moderately or significantly. Project 18 was terminated in the design phase due to a change of ownership of the project. Project 21 ended prematurely due to administrative obstructions. The realization phase of project 24 has not yet been commenced. 
Table 1. Evaluation of individual projects (source: authors based on [5])

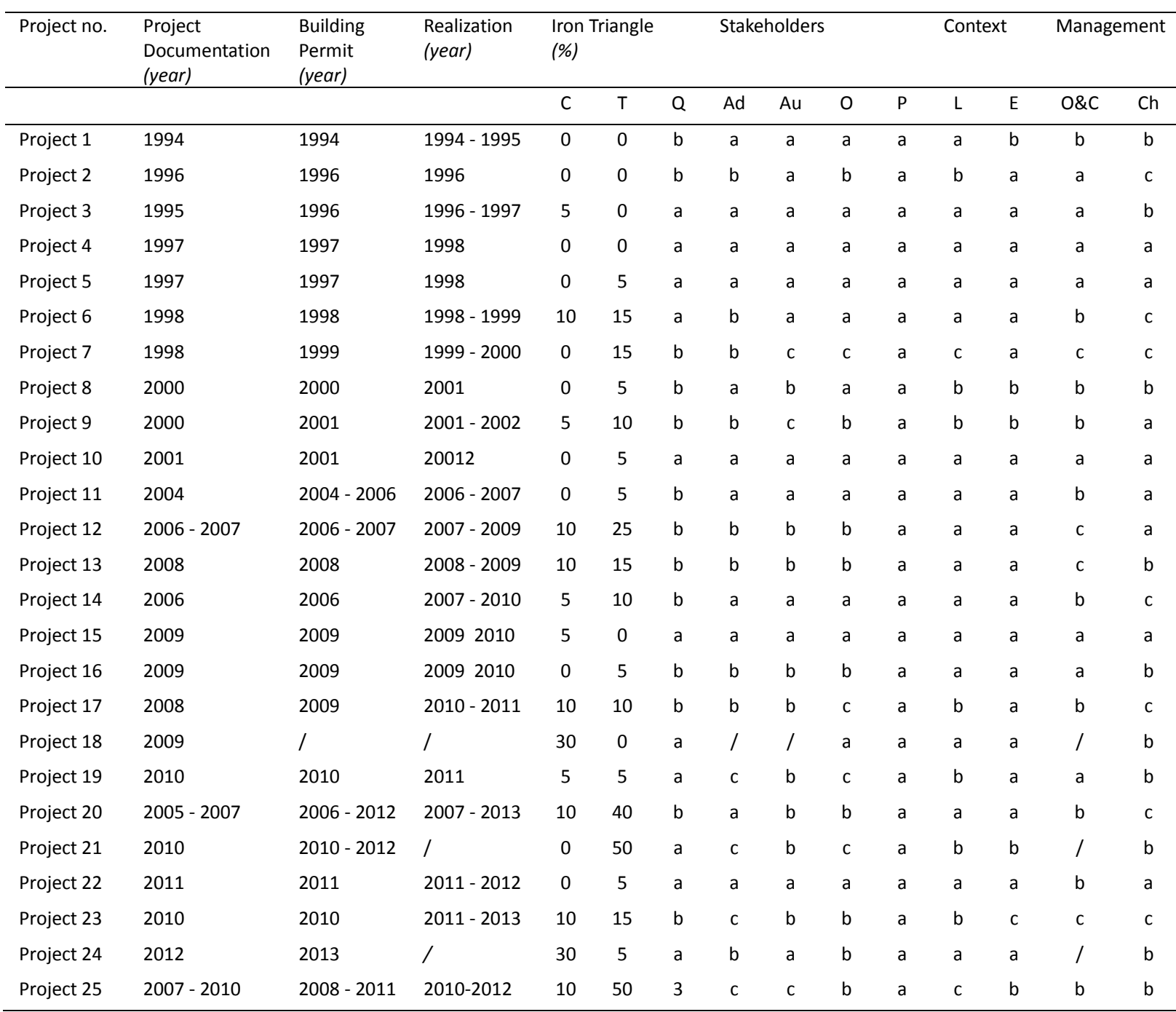

C - Cost; T - Time, Q - Quality, Ad - Administration; Au - Authority; O - Neighboring property owners; P - Public, L - Legal; E Environment; O\&C - Organization and Communication; $\mathrm{Ch}$ - Changes.

Based on data provided by civil engineering company IVP Servis, 2014.

This study verified that the proposed factors influence the success of construction projects and should be taken into account in project management.

\section{Conclusion}

Based on a sample of projects we presented a possible approach to evaluating a project's success. As we demonstrated, apart from the basic Iron triangle criteria it is necessary to also include other criteria in the evaluation. An assessment of the sampled projects clearly suggests that even small projects require taking the Stakeholders group of criteria into account. Stakeholder groups are a significant factor that impacts a project's success. The groups' representation, size and activity varies for different types of projects.

Every project is also influenced by additional factors represented by the Context group of criteria. The significance of these criteria is proportional to the project's scale and complexity. Indispensable are also criteria connected with project management. 


\section{References}

[1] ATKINSON, R. Project management: Cost, time and quality, two best guesses and phenomenon, its time to accept other success criteria. In: International Journal of Project Management, 1999, vol. 17, no. 6, pp. 337-342. https://doi.org/10.1016/S0263-7863(98)00069-6

[2] ERNST \& YOUNG, Průzkum rízení projektů v ČR a SR 2013. [online] Ernst \& Young, 2013, Available at: <http://www.ey.com/Publication/vwLUAssets/Pr\%C5\%AFzkum_\%C5\%99\%C3\%ADzen\%C3\%AD_2013/\$ FILE/EY_Pruzkum\%20rizeni\%20projektu\%20v\%20CR\%20a\%20SR\%202013.pdf> [Accessed 25 February 2014]

[3] ERNST \& YOUNG, Průzkum rízení projektů v ČR a SR 2012. [online] Ernst \& Young, 2012, Available at: http://www.ey.com/Publication/vwLUAssets/PMP_Survey_2012/\$FILE/EY_Pruzkum\%20rizeni\%20proje ktu\%20v\%20CR\%20a\%20SR\%202012.pdf [Accessed 25 February 2014]

[4] INTERNATIONAL STANDARD OFFICE, ISO 21500 Guidance on project management. 2012, Geneva: ISO.

[5] IVP SERVIS, Internal database of contracts. 2014. Prague.

[6] MUNNS, A. K., BJEIRMI, B. F. The role of project management in achieving project success. In: International Journal of Project Management, 1996, vol. 14, no. 2, pp. 81-87. https://doi.org/10.1016/0263-7863(95)00057-7

[7] OLANDER, S., LANDIN, A. Evaluation of stakeholder influence in the implementation of construction projects. In: International Journal of Project Management, 2005, vol. 23, pp. 321-328. https://doi.org/10.1016/j.ijproman.2005.02.002

[8] PROJECT MANAGEMENT INSTITUTE, A Guide to the Project Management Body of Knowledge (PMBOK) - 2013, Fifth edition. Pennsylvania: PMI.

[9] WAI, S.H., AMINAH MD YUSOF, SYUHAIDA ISMAIL, C. A. NG, Expoloring Success Factors of Social Infrastructure Projects in Malaysia. In. International Journal of Engineering Business Management, 2013, vol. 5, no. 2, pp. 1-9.

[10] WESTERVELD, E. The Project Excellence Mode ${ }^{\circledR}$ : linking success criteria and critical success factor. In: International Journal of Project Management, 2003, vol. 21, pp. 411-418. https://doi.org/10.1016/S0263-7863(02)00112-6

[11] COOK-DAVIES, T. The "real" success factors on projects. In: International Journal of Project Management, 2002, vol. 20, pp. 185-190. https://doi.org/10.1016/S0263-7863(01)00067-9 